\title{
Quantifying Embodied Energy Using Green Building Technologies under Affordable Housing Construction
}

\author{
Nand Kishore Gupta ${ }^{1}$, Anil Kumar Sharma ${ }^{2}$, Anupama Sharma ${ }^{2}$ \\ ${ }^{1}$ M.P. Housing \& infrastructure Development Board, Bhopal, India \\ ${ }^{2}$ Maulana Azad National Institute of Technology, Bhopal, India \\ Email: nerkar17@rediffmail.com
}

Received October 22, 2013; revised November 22, 2013; accepted November 27, 2013

Copyright (c) 2013 Nand Kishore Gupta et al. This is an open access article distributed under the Creative Commons Attribution License, which permits unrestricted use, distribution, and reproduction in any medium, provided the original work is properly cited.

\begin{abstract}
The building construction industry is a major contributor of environmental pollution, with high levels of energy consumption and greenhouse gas emissions, all of which contribute to climate change. Housing is the single largest subsector of the construction industry. It is also a basic need associated with social and economic benefits, and its demand in most emerging economies is substantial. Hence it is a sector with significant potential not to mitigate just the negative impact of climate change on buildings and people, but also to reduce the impact of the construction industry on the natural environment. Green buildings technology has advanced greatly in recent years, but most "high performance" green buildings are capital intensive, often with high-tech applications that are not in easy reach of the mass housing market. In the developing country context, where huge segments of the population lack access to essential services or housing, the green buildings approach to addressing climate change is perceived to be largely unaffordable. For green technology to be adopted in poorer nations and have scalable impact, it will have to be low-cost and affordable. According to a 2010 report, buildings in the commercial, office and hospitality sectors are poised to grow at $8 \%$ annually over the next 10 years in India. While the retail sector has been growing rapidly at $8 \%$ per annum, the residential sector has seen growth of $5 \%$ per annum during this period. It is estimated that over 70 million New Urban Housing Units will be required over the next 20 Years.
\end{abstract}

Keywords: Affordable Housing; Embodied Energy; Green Technology

\section{Introduction}

Work on green housing so far has been largely limited to standalone projects and projects catering to upper middle and high income groups, even mostly on commercial projects, with main stream developers only recently entering the green housing construction. In the affordable housing projects, the use of green building technology and systems has been limited, or even negligible.

For any significant environmental impact, green technologies and materials need to penetrate the mainstream housing industry. In other words, green housing appeals to a much wider audience, i.e. viewed as a socially responsible and commercially viable proposition for the common builder/developer, and an economically and socially viable proposition for the average end user. Once such transformation begins in the organized real estate market, the rest of the market is likely to pick up on it, with a catalytic effect on improving the environment.
The energy in buildings consumed in two different ways

- Energy that goes into the construction of the building using a variety of materials.

- Energy that is required to create a comfortable environment within the building.

Very few studies regarding the energy consumed during the maintenance of the building (heating, cooling and lighting) have been published. However the assessment of the embodied energy in buildings is still in its nascent stage in India and requires serious research.

The concept of green buildings is still at an emerging stage in India and concept of sustainable buildings and use of environmentally friendly construction materials like stones, timber, thatch, mud etc. have been practiced since ancient times. But the perception of people about strong and durable buildings have changed with the development and invention of modern materials like steel, cement, aluminium, glass etc. A large amount of fuel energy gets consumed in producing such materials. 
These materials produced in industries further need to be transported to large distances before getting assemmbeled in the buildings, which further consumes energy. An estimate of the energy consumed in buildings using different permutations of materials and techniques will facilitate their appropriate selection and reduce the embodied energy consumption.

In this context, this study seeks to present the case for incorporation of green technologies, materials, and systems in the affordable housing sector in a tangible and quantifiable manner. To quantify the saving achieved in embodied energy using green technology, a case study for the construction of 600 EWS houses is considered under the climatic condition of Bhopal (M.P.). This study is focused on taking an integrated approach to address the issues of low cost sustainable technology system, their implication on large scale projects and their cultural acceptance for affordable housing construction. Study includes, identifying various available green technologies, which are technically viable, socially acceptable and quantifying embodied energy consumption including environmental impacts of conventional construction technology over green housing techniques.

\section{Embodied Energy [1]}

The embodied energy is the energy required to construct and maintain the campus, for example, in reinforced concrete construction, the energy required to quarry the coarse and fine aggregate, transport them to site, lay them, plaster them and (if necessary) paint and re-plaster over the life of the respective element. Best practice would also include energy calculations for demolition and recycling. A flowchart mentioning various activities involved from quarry of the material to the final finished product of the elements, required to estimate embodied energy is given in Figure 1. Debate continues about the boundaries that should be applied to calculate embodied energy. Commonly, the most influential components of embodied energy are those bounded by the cradle to gate approach, that is, all the energy required to deliver the product to the gate of the factory ready for transport to the construction site. Even within an embodied energy calculation bounded "cradle to gate" the complexity of embodied energy could be extreme.

For example, the energy used by the factory in the processing or manufacturing process may be easily identified, however what about the energy used by the employees:

- Transport Fuel (to and from work).

- Embodied energy of transport (to and from work).

- Energy of services (health, legal, accounting).

- Energy to produce food to feed the workforce (transport, agriculture, refrigeration).

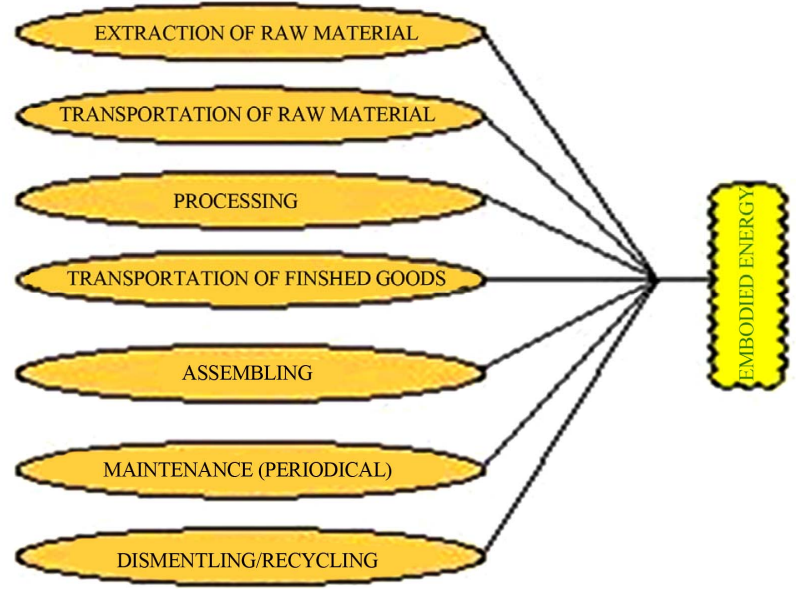

Figure 1. Components of embodied energy.

Any one point in the processing and manufacturing chain can be analyzed in detail chasing endless trail of energy calculations back to the Stone Age. With this in mind, it is important to remember the purpose of embodied energy calculations, it is to make informed decisions that lead to improvements in the way we use energy.

At present, order of magnitude accuracy would generally satisfy this purpose. The approach discussed in this paper is built on this principal.

\section{Housing Demand in India [2]}

Based on a study of residential housing demand in India, it is estimated that the additional demand for urban housing forecasted in India for 2012-13 is about 6.79 million. By 2015 the additional demand for housing is projected at 31 million, and that a large proportion of this will be required in the affordable sector. It is estimated that over 70 million new urban housing units will be needed over the next 20 years (see Figure 2).

The analysis is based on the 11th Year Plan report by Planning Commission and derives an annual growth rate of nearly $4 \%$ in housing. People migrating from periurban areas to urban areas will also add to this projection of housing demand.

Dr. P. S. Chani [3] in his study presented the embodied energy rates (EER) for a range of walling elements. These elements have been obtained by using combinations of alternative building blocks and mortar mixes. Through the tabulated data, a comparative analysis has been carried out to gauge the energy efficiency of the walling elements and to identify the most suitable option. The study also highlights the significant reasons, which lead to an energy efficient alternative.

Krishnakedar S. Gumaste [4] presented their work on computation of embodied energy in buildings and addressed the issues and problems with the materials and technologies used in building industry, in the study at- 


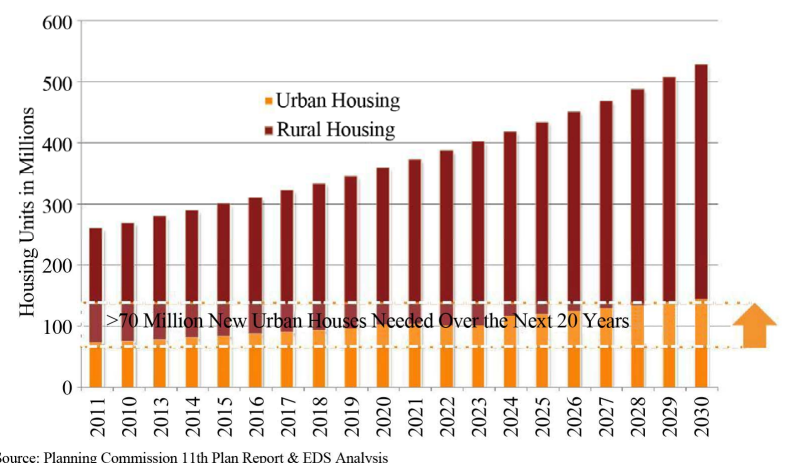

Figure 2. Housing demand in India.

tempts have been made towards the assessment of embodied energy in various types of building with different number of stories of the buildings.

Talakonukula Ramesh et al. has [5] presents life cycle energy analysis of a multifamily residential house situated in Allahabad (U.P), India. The study covers energy for construction, operation, maintenance and demolition phases of the building. The selected building is a 4-storey concrete structured multifamily residential house comprising 44 apartments. The material used for the building structure is steel reinforced concrete and envelope is made up of burnt clay brick masonry. Embodied energy of the building is calculated based on the embodied energy coefficients of building materials applicable in Indian context. Operating energy of the building is estimated using e-Quest energy simulation software.

\section{Case Study}

A typical unit of EWS houses being constructed under affordable housing project by Madhya Pradesh Housing and Infrastructure Development Board in Bhopal (M.P.) India is considered as a prototype model. Details of the plan are as under

Building type:

- Ground floor row housing.

- 1 BHK Units $~ 30.5$ sqm.

- Area of Openings $6.5 \mathrm{sqm}$.

- Shading deviceschajja projection $400 \mathrm{~mm}$. Family profile

- Family of four:

- Husband, wife \& 2 Children. Appliances in use

- CFLs.

- 1 Refrigerator.

- $1 \mathrm{TV}$.

- Ceiling Fans 1 Evaporative Cooler. Typical energy use Average Electricity Bill Rs. 280/Month ( 100 kWh/ Month)

- A cooking gas cylinder of $14.5 \mathrm{~kg}$ lasts one month. Financial profile
- Family Income Rs. 11,000/Month.

- Monthly Rental Rs. 1500/Month.

- Current Market Cost of the Apartment Rs. 750,000.

Based on the architectural drawings Figures $\mathbf{3}$ and $\mathbf{4}$ and specifications, the details of bill of quantities and embodied energy along with the $\mathrm{CO}_{2}$ produced is calculated, represented in Figures $\mathbf{5}$ and $\mathbf{6}$ respectively.

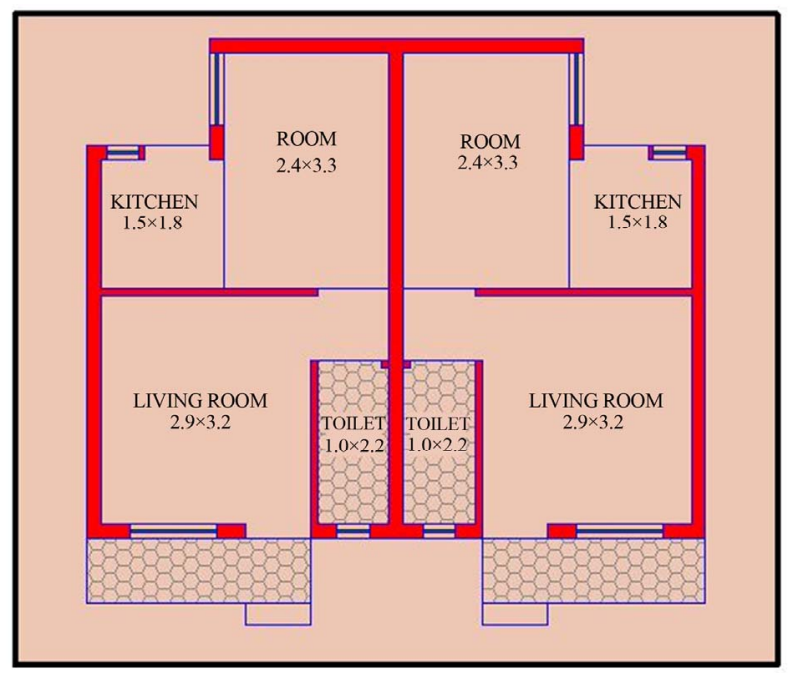

Figure 3. Case study building plan in Bhopal, India.

EXPENDITURE ON VARIOUS HEADS

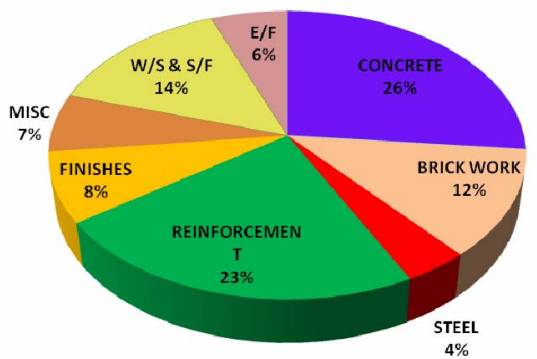

Figure 4. Percentage share of construction cost on various heads.

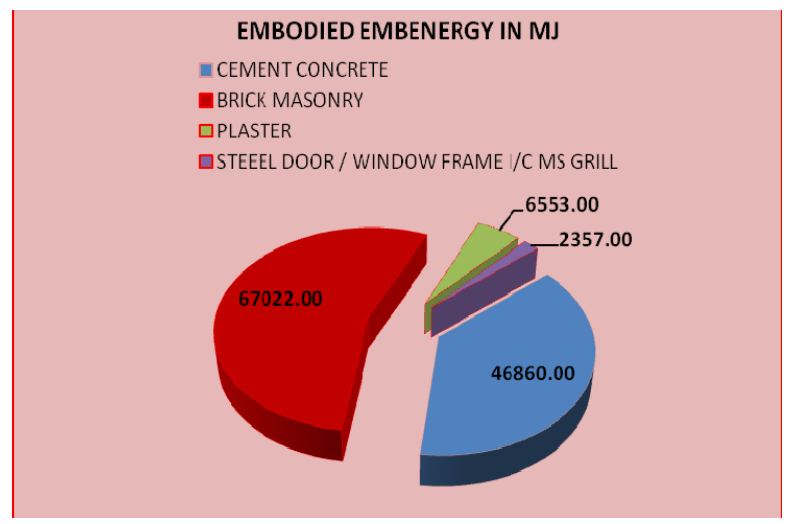

Figure 5. Amount of embodied energy for major construction activities. 


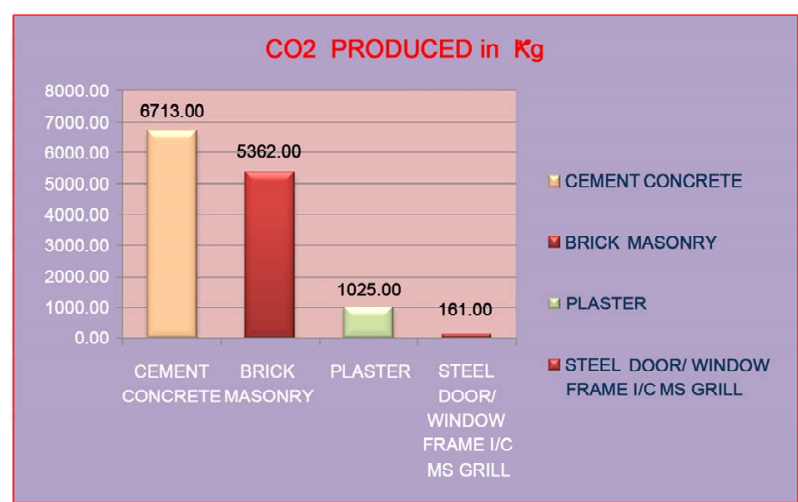

Figure 6. Amount of $\mathrm{CO}_{2}$ produced for major construction activities.

\section{Construction Cost}

In building construction it is observed that wall systems, roofing and wood work for doors and windows accounts for almost $65 \%$ of the entire construction cost, since purpose of the study was to quickly arrive at the list of affordable green technologies, hence greater attenuation is provided towards green technologies available to these components, which contributes 65\% (Figure 3) of the entire construction cost. Walls, Roofs, Floors, Fenestration, Framing, Partitions and Doors are the various building components which are essentially required for any type of building construction, a conventional technology is considered as a datum to compare green technology.

Quantity of embodied energy based on IIEC report calculated and represented in Figure 5, it is observed that embodied energy in bricks worked out to be the highest one and needs to be taken care of. Similarly another major contribution of embodied energy is from cement concrete, hence these two materials are required to be replaced with some other alternative materials, which can save significant amount of embodied energy. Similarly, amount of $\mathrm{CO}_{2}$ emission for above two building materials is represented by Figure 6 .

Based on various aspects with lowest environmental impacts in terms of embodied energy, some of the technologies are listed in the Table 1. For few technologies, marginally higher initial costs than the baseline technology are acceptable because of substantially lower environmental costs and short payback periods.

Above mentioned technologies are environmental friendly and consume least amount of embodied energy, comparative analysis for the wall and roofing material are mentioned in the succeeding tables.

Various green building technologies are listed in Table 1. In construction of low cost affordable housing units it can be observed that use of white reflective paint for the roof treatment can be one of the solution, which will not only cost effective, but also helps in reducing the
Table 1. Technologies for various elements of building [6].

\begin{tabular}{|c|c|c|}
\hline Technology & Advantages & Challenges \\
\hline Whit & $\begin{array}{ll}\text { - } & \text { Energy-efficient } \\
\text { - } & \text { Improved thermal comfort } \\
\text { - } & \text { Cost effective }\end{array}$ & $\begin{array}{l}\text { Frequent } \\
\text { application is } \\
\text { required }\end{array}$ \\
\hline y Ash Bricks & $\begin{array}{ll}\bullet & \text { Does not involve burning } \\
\text { s } & \text { Improved strength \& durability } \\
\text { - } & \text { Reuse of Industrial wastes }\end{array}$ & $\begin{array}{l}\text { Water requirement } \\
\text { is more }\end{array}$ \\
\hline $\begin{array}{l}\text { Hollow Con- } \\
\text { crete Block }\end{array}$ & $\begin{array}{ll}\text { - } & \text { Light Weight } \\
\text { - } & \text { Good Thermal Insulation } \\
\text { - } & \text { Low cost of mortor } \\
\text { - } & \text { Can be cast in situ } \\
\text { - } & \text { Low embodied energy }\end{array}$ & $\begin{array}{l}\text { Equipment } \\
\text { required }\end{array}$ \\
\hline $\begin{array}{l}\text { Reflective } \\
\text { Roof Tiles }\end{array}$ & $\begin{array}{l}\text { - Reduces operational energy } \\
\text { - Improved thermal comfort } \\
\text { - Low cost }\end{array}$ & $\begin{array}{l}\text { Extra expenditure, } \\
\text { as not a part of } \\
\text { structure }\end{array}$ \\
\hline Fille & $\begin{array}{ll}\text { - } & \text { Reduced quantity and weight of } \\
\text { material } \\
\text { - } & \text { Cost effective } \\
\text { - } & \text { Enhanced thermal comfort } \\
\text { - } & \text { Low embodied energy }\end{array}$ & $\begin{array}{l}\text { Required skilled } \\
\text { labour for } \\
\text { implementation }\end{array}$ \\
\hline R C & $\begin{array}{ll}\text { - } & \text { Conserves precious natural } \\
& \text { resource-wood } \\
\text { - } & \text { Cost-effective } \\
\text { - } & \text { Can be pre-fabricated on site } \\
\text { - } & \text { Improved strength \& durability }\end{array}$ & $\begin{array}{l}\text { Availability is a } \\
\text { problem in mass } \\
\text { housing projects }\end{array}$ \\
\hline
\end{tabular}

indoor temperature and ultimately reduces operational cost, only its repetitive application will be a recurring expenditure. Similarly use of RC frames should also be encouraged, for which availability of the same should be ensured so that, it can be used in affordable dwelling units. Other building materials have also been mentioned along with its advantages and challenges to be faced for its use in building industry.

Tables 2-4 gives the quantity of embodied energy for various materials used in wall, roof and door/window frames respectively. In walls of the building use of traditional bricks should be replaced with hollow concrete blocks, which consumes only $31.45 \%$ energy as required to make traditional bricks, while, white reflective paint will require only $2.7 \%$ of energy. Further use of precast door frame will almost be produced with negligible amount of energy, which otherwise would be required to produce steel door frame.

\section{Summary and Conclusions}

Attempts in minimizing or replacing the conventional high energy materials like cement, steel, bricks withcheaper and local alternatives will lead to the reduction in the embodied energy in buildings.

Materials like Cement, Steel and Bricks and Glass are the major contributors to the total energy consumption in RC buildings.

1) The use of alternative building units like hollow 
Table 2. Estimate of embodied energy for various wall material [7].

\begin{tabular}{cccc}
\hline Material & Embodied Energy MJ/sqm of surface area Embodied Energy MJ/sqm of floor area & Percentage with base case \\
\hline Base Case: Bricks & 615 & 1139.9 & $39.37 \%$ \\
Flyash Lime Gypsum Bricks & 242 & 448.8 & $31.45 \%$ \\
Hollow Concrete Blocks 200 mm & 193 & 358.39 & $31.75 \%$ \\
Compressed Stabilised Earth Bricks & 195 & 361.64 & \\
\hline
\end{tabular}

Table 3. Estimate of embodied energy for various roofing material [7].

\begin{tabular}{cccc}
\hline Material & Embodied Energy MJ/sqm of surface area & Embodied Energy MJ/sqm of floor area & Percentage with base case \\
\hline Base Case: RCC & 847 & 847 & $4.0 \%$ \\
High Albedo Roof (Reflective Tiles) & 34 & 34 & $2.7 \%$ \\
High Albedo Roof (White Coating) & 23 & 23 & $69.65 \%$ \\
RCC Filler Slab & 590 & 590 & \\
\hline
\end{tabular}

Table 4. Estimate of embodied energy for various door window frame material [7].

\begin{tabular}{cccc}
\hline Material & Embodied Energy MJ/sqm of surface area & Embodied Energy MJ/ sqm of floor area & percentage with base case \\
\hline Base Case: Steel & 8873 & 6651.49 & $0.4 \%$ \\
Pre Cast Door Window Frame & 288 & 25.63 & $0.1 \%$ \\
Wood Plastic Composite & 67 & 5.99 & \\
\hline
\end{tabular}

concrete blocks for masonry construction reduces the energy consumption by $69 \%$ as compared to brick masonry.

2) The conventional RC roof is energy intensive with embodied energy values of $847 \mathrm{MJ} / \mathrm{m}^{2}$. The RCC filler slab roof almost saves $31 \%$ energy as compared to the RC roof, where as White Paint and Reflective tiles consumes embodied as low as $4 \%$ and $2.7 \%$ of RCC roof.

3) Almost 99\% of embodied energy can be saved using Pre Cast RCC Door Window frame or Wood Plastic Composite frame with respect to conventional steel door window frame.

\section{REFERENCES}

[1] Embodied Energy. http://en.Wikipedia.org/wiki/Embodied Energy

[2] A Bandyopaphyay, "A Study of Housing Demand in India," MPRA Paper Number 9339, NIBM-NHB, 2008.
[3] P. S. Chani, et al., "Comparative Analysis of Embodied Energy Rates for Walling Elements in India,” IE(I) Journal-Architectural Engineering, Vol. 84, 2003, pp. 47-50.

[4] K. S. Gumaste, "Embodied Energy Computations in Buildings,” Advances in Energy Research (AER-2006), pp. 404-409.

[5] T. Ramesh, et al., "Life Cycle Energy Analysis of a Multifamily Residential House: A Case Study in Indian Context," Open Journal of Energy Efficiency, Vol. 2, No. 1, 2013, pp. 34-41.

[6] "Identification of Low Cost Green Options and Their Macro-Environmental Impact,” Final Report, 2011

[7] Affordable Housing Energy Efficiency (AHEE), "Affordable Housing Energy Efficiency Handbook,” 2007. http://www.h-m-g.com/multifamily/AHEEA/Handbook/d efault.htm 